\title{
Consideration of Experimental Teaching on College Financial Management Major
}

\author{
Shanxiang Liang \\ Business School, Sichuan Agricultural University, Dujiangyan Sichuan, 611830, China
}

Keywords: College financial management, Experimental teaching, Consideration.

\begin{abstract}
With the increasingly fierce market competition in China, higher requirements have been put forward for the financial management professionals. Since the financial management, as one of the most important course in accounting major, its teaching model should also change with the market economic development, so as to meet the social demand for high-quality personnel. This paper describes the importance of experimental teaching for financial management in colleges and the current status of teaching, and then the related content of design experimental teaching of financial ,management in different levels will be explored, and finally put forward some suggestions for the experimental teaching of college financial management major.
\end{abstract}

\section{Introduction}

In college accounting profession, financial management as one of the most important a subject, the content of this discipline included is to allow students to learn how to deal with financial matters relating to enterprises in the production activities in the face, but also need to master the enterprises in the production course of business related financial management activities. Its ultimate purpose is not only to students with a solid theoretical foundation of knowledge, should as soon as possible to establish the correct financial concept, so as to better improve the overall capacity of financial management. Various universities in China to continue to improve the standard of teaching, and teachers of this discipline will be continuous training so that teachers have more teaching methods. But since this has a strong hands-on operational discipline. From the point of view of teaching theoretical knowledge, our colleges and universities, or more emphasis on teaching the theory, practice operating contempt Course. Experimental teaching as a means to supplement theoretical knowledge, have a very important role in teaching, on the one hand not only allows students to understand and master the basic theoretical knowledge of financial management, on the other hand can also continue to improve the students' practical training and hands-on ability. Therefore, the establishment of experimental teaching system in colleges and universities specializing in financial management is necessary, this paper analyzes how to construct a scientific, experimental education system.

\section{Status of the Financial Management Experimental Teaching}

\section{Experimental System Lacks Integrity.}

Since the content of financial management theory class included more, but in general the experimental courses offered relatively few. So the majority of colleges and universities are more emphasis on theoretical knowledge, ignoring the practical teaching. While most universities have a complete set of experimental teaching system, but the experiment courses offered are basically doing vouchers, statements, etc, since that school easier. Even so the school opened a class experiment, basically the equivalent of theoretical knowledge of students learning were reviewed, and does not reflect their own unique characteristics. With the rapid social and economic development, most of the universities have begun to establish a training base in the school, so you can train more talents to meet social demands. If a student intern in the financial management mechanism, since the financial management has high confidentiality, etc., even if the students to practice, but also contact with some relatively simple task, to hands-on practice is very difficult. For the school to establish training base in the school is just a form. 


\section{Experimental Content Lacks Comprehensiveness.}

Due to the experimental content of financial management more professional and theoretical aspects, but in actual practice, the practice of the textbook theory of knowledge, are basically content-based review, and not really implemented in practice. However, due to financial enterprises need a comprehensive talent, but colleges and universities are trained people and businesses required far. Even so the school set up this experiment course, is not conducive to students found the problem and solve the problem with this capability. In the experimental teaching process, try to take a more authentic teaching case teaching, so as to give students to create a true experiment teaching environment. Such as: can select Lenovo Group's acquisition of IBM's case for students on merger-related content through this real case teaching, not only can fully mobilize the students' enthusiasm, but also train them when they encounter problems can seek their own solution to the problem ability. Now, however, although mostly textbooks to real business name, under normal circumstances in order to achieve good experimental teaching effect, its specific content and the reality there is still a gap.

\section{The importance of financial management experimental teaching}

\section{Experimental Teaching is the Main Route for Students to Take Theoretical Knowledge to Practice.}

In college financial management teaching, is to explain the basic theoretical knowledge of financial management based, such as: how companies and investors, customers and other how to get along, are closely related to the existence of interests between them; how companies use less the funds raised more money; in the enterprise's production and business activities, and how you can better manage business operations of funds ${ }^{[1]}$, in the future if corporate earnings, how to distribute the profits, and so on. If every day in the classroom for students to learn the theoretical knowledge, they will feel special boring, boring, or even lose interest in learning. But if the experiment teaching, students can experience how to solve the financial problems encountered by businesses, and the theoretical knowledge learned into practice, can not only improve the teaching level, can fully mobilize the students have interest in learning, so that students in the learning process to proactively identify financial problems and practical problem-solving skills.

\section{Experimental Teaching Provides a Platform for by Helping Students Improve Their Overall Ability.}

In the financial management process of teaching, teaching methods adopted is the teacher in the above talks, the students in the following listening, doing an experiment, the students make their own teachers to assist in the next, some teachers also use multimedia tools to students continues instill basic theoretical knowledge, such teaching methods, so that students can only passively accept. However, if the use of experimental teaching ${ }^{[2]}$, allows students to simulate experiments via computer network platform, can greatly improve student learning initiative. Through teaching, students can not only be further enhanced in the hands, brains, cooperate with each other and so on. In the experimental teaching process, students can also take advantage of the theoretical knowledge learned, in the face of financial problems, and the combination of theoretical knowledge to analyze, to find solutions to problems. Thus, the creation of the College Financial Management in the experimental teaching to improve students 'basic financial awareness and a deeper understanding of the course of the experiment can develop students' ability to actively explore the problem, in turn, can train students in practical ability, innovation capabilities have been further improved.

\section{Content Design of Financial Management Experimental Teaching}

\section{Training Objectives and Capacity Requirements Aim for Professional Needs of Financial Management Major. \\ Because of College Financial Management Undergraduate cultivated talents goal is to meet the requirements of the application-oriented society, integrated talent. Students after graduation career are engaged in corporate finance director, finance and financial analysts as the main training}


objectives. From this training goal, the students should have a more solid theoretical foundation of knowledge, but also familiar with our knowledge of all aspects of financial regulations and relevant international laws and regulations, but also to accept more stringent financial management training in order to improve students with higher management capabilities and skills; in the face of financial problems, with a strong ability to analyze problems and problem-solving ability. From should have in terms of overall quality and ability, not only to language students' organizational ability, good communication, in dealing with interpersonal relationships, interpersonal and other capabilities, but also has the ability to continue to innovate, innovative spirit and so on. Since part of corporate financial management is relatively complicated, but also more prone to changes in the future for enterprise financial management, should not be only in accordance with a conventional method to solve the problem in the face of problems, but the need to constantly improve their professional sensitivity and it has a strong sense. Thus, in the experimental teaching curriculum process, not only make the entire experimental teaching system has some integrity, but also according to the capacity of the social objectives required to train students.

\section{Content Design for Multi-level, Multi-step Advance of the Financial Management Experimental Teaching .}

Financial management teaching content design, not only to highlight the unique characteristics of their profession, but also in the design of teaching content ${ }^{[3]}$, to be based on professional training objectives and requirements, so as to design a complete set of teaching system. It consists of four levels, which formed stepwise advancing financial management teaching content.

The first level: to further improve students' practical skills in information processing and financial software business. Design of this pilot project is to allow students to practice through training to improve the content of accounting, computerized basic experiments and other basic operational capability for the more skilled students with the basic operation capability, as soon as possible to enable students to understand and master the basic theory of the experiment, knowledge, and lay a solid foundation for higher-level experiments. In the teaching process, the software can be computerized in various applications into many small pilot projects, such as: frequently used functions to draw basic financial analysis chart, and so on.

The second level: to improve and consolidate the basic methods and skills in financial management. Designed to the financial management of the important programs related to teaching content, learning can not only improve and consolidate financial management methods and skills, also allows students to experiment by teaching basic theoretical knowledge consolidation. Allow students to learn on their own professional we have a clearer framework. Thereby it needs to enhance the students' hands-on operational capability.

The third level: focus on training and improving students' ability to target financial decisions of simulation. For financial management simulation, not only for students through the specific operation process simulation environment, in a simulated environment based on the experimental requirements, so that the students yourself practice, and in accordance with the actual situation of enterprise financial management for enterprise investment, profit distribution, preparation reports, etc., as your own work in the corporate finance department of the same, and thus the overall financial management workflow more in-depth understanding.

The fourth level: to improve students' comprehensive ability to target business of ERP Sand Game Experiment Teaching. ERP system as the core system of financial management, as financial officers, must be familiar with each workflow; we need to have some practical ability. Financial management students to be familiar with both the master enterprise system liquidity, information management systems, should also have some practical skills ${ }^{[4]}$, you can better handle the relationship between finance. Currently, many universities have opened ERP sandbox classroom teaching, further training senior financial management personnel to provide a good practice platform, so the financial management teaching process should make better use of this platform.

Through more than four levels of teaching content, we need these four layers experimental teaching are closely linked, and layers, and after a rigorous financial management training later 
learned theoretical knowledge and practical work combined, and then continue to improve their ability and innovative ability ${ }^{[5]}$.

\section{Financial Management Experimental Teaching Organization}

\section{Continue to Strengthen the Experimental Teaching Link.}

In the process of teaching financial management, under normal circumstances are teaching emphases on theoretical knowledge, often overlooked experiment teaching process, which would result in relatively poor experimental teaching, the teacher is no enthusiasm in the teaching process, students lose interest in learning. Therefore, in order to further improve the level of experiment teaching, improve students' interest in learning, we must continue to strengthen the experimental teaching. Teachers can develop different experimental teaching curriculum design according to the teaching content, so that the experimental and theoretical knowledge curriculum design combined, and thus form a hierarchy, a strong purpose a complete set of experimental teaching system.

\section{Improving Teachers' Comprehensive Quality.}

Financial management courses teaching process, basically there will be various forms of monitoring group teaching examination, but supervision team is relatively small and the experimental teaching curriculum examination, experimental teacher training courses and even fewer. Therefore, in order to further improve the quality of teaching experiments, we need to constantly improve the overall quality of teachers. On the one hand we can take a variety of ways for training teachers, in order to improve teachers' hands-on practical skills. For example: we can arrange suitable experimental teaching teachers to business contact with some actual work content, which can increase teachers' practical experience. On the other hand, schools can develop a number of incentives; this can increase the power of teachers in the teaching process.

\section{Establish Effective Evaluation Method.}

Under normal circumstances, the majority of colleges and universities for financial management, only concerned about student achievement, seriously neglected the experimental teaching process, leading students and teachers will ignore this important part of the experiment. In order to better improve the quality of teaching experiment, it is necessary to establish relevant evaluation of Experimental Teaching. In the experimental teaching process should focus on assessing the students to actively participate in the experimental teaching process performance. For the students to observe the problem during the experiment, analyze and address the specific performance-solving skills in order to develop with the corresponding assessment methods. For example: You can assess student engagement in the course of the experiment, the preparation of test reports and other regulatory aspects.

\section{Conclusion}

In summary, the practice of teaching has a very important role in the college financial management teaching, in order to further meet society needs high-quality personnel, professional financial management of colleges and universities in order to train students in applied, technical talents as Lord, so they can better adapt to the rapid development of society. Application of financial management in teaching experimental teaching, one can improve students' financial management capacity, on the other hand can also train students to employment as the financial management capacity of the wizard requirements.

\section{References}

[1] Li Hong. Path Selection for Experimental Teaching Reform and Innovation of College Financial Management Major - Taking Huizhou University Financial Management as An Example, Huizhou University Journal, 2012,32 (1): 115-117,128.

[2] Wu Yaling. On the Consideration of Experiment Teaching for College Financial Management, 
Industry Technology Summit, 2012, (10): 154-155.

[3] Li Zhen, Peng Yang. The Pre-test of Effect Appraisal System for Economics Colleges Financial Experimental Teaching, China Township Enterprises Accounting, 2011, (3): 166-167.

[4] Peng Xiaofeng. Thinking on Financial Management of Experimental Teaching, Economic Research Guide, 2011, (3): 251-252.

[5] Wang Ya. Discuss on College Financial Management Course Experimental Teaching System Reform, Science Week, 2015, (18): 10. 